\title{
Ecotoxicological Effects of Ibuprofen on Plant Growth of Vigna unguiculata L.
}

\author{
Leonard Wijaya ${ }^{1, *}$, Mohammed Alyemeni ${ }^{1}$, Parvaiz Ahmad ${ }^{1}$, Ahmed Alfarhan ${ }^{1}$, \\ Damia Barcelo ${ }^{1,2}{ }^{\mathbb{D}}$, Mohamed A. El-Sheikh ${ }^{1}$ and Yolanda Pico ${ }^{3}$ \\ 1 Department of Botany and Microbiology, College of Science, King Saud University, P.O. Box 2455, \\ Riyadh 11451, Saudi Arabia; mnyemeni@ksu.edu.sa (M.A.); pahmad@ksu.edu.sa (P.A.); \\ alfarhan@ksu.edu.sa (A.A.); dbcqam@cid.csic.es (D.B.); melsheikh@ksu.edu.sa (M.A.E.-S.) \\ 2 Water and Soil Quality Research Group, Department of Environmental Chemistry, IDAEA-CSIC, \\ Jordi Girona 18-26, 08034 Barcelona, Spain \\ 3 Environmental and Food Safety Research Group (SAMA-UV), Desertification Research Centre \\ CIDE (CSIC-UV-GV), Faculty of Pharmacy, University of Valencia, Av. Vicent Andrés Estellés s/n, \\ 46100 Burjassot, Valencia, Spain; Yolanda.Pico@uv.es \\ * Correspondence: lwijaya@ksu.edu.sa; Tel.: +966-11-4675873
}

Received: 21 October 2020; Accepted: 29 October 2020; Published: 2 November 2020

\begin{abstract}
Despite the prevalence of the common pharmaceutical ibuprofen (IBU) in water and sediments worldwide, the effects of IBU on plants are largely unknown. This study was designed to assess the ecotoxicological effects of emerging pharmaceutical pollutant IBU on plant growth and development in a series of toxicity experiments using cowpea (Vigna unguiculata). Plant growth parameters (morphological and physicochemical) were investigated under a series of IBU concentrations $(0,400,800,1200,1600,2000 \mathrm{ppm}$ IBU). IBU exposure reduced the shoot and root lengths, fresh and dry weights, leaf area, and chlorophyll a and b, carotenoid, total chlorophyll, mineral (K and $\mathrm{Mg}$ ), glutathione reductase, and soluble protein contents. Simultaneously, increases in Ca and $\mathrm{Mn}$ contents, sodium translocation from roots to shoots, $\mathrm{H}_{2} \mathrm{O}_{2}$, malondialdehyde, superoxide dismutase, catalase, ascorbate peroxidase, and IBU uptake were observed. The amount of bioaccumulated IBU varied between $7 \%$ and $8 \%$. IBU was translocated from roots to shoots with a translocation factor of 3-16\%. The $\mathrm{IC}_{50}$ values for biomass and plant length were 1253 and 1955 ppm IBU, respectively, which is much higher than the reported levels of IBU in the environment. This study demonstrates that cowpea plants develop several morphological and physicochemical adaptations to cope under ibuprofen stress; environmentally relevant concentrations of IBU are unlikely to produce negative impacts.
\end{abstract}

Keywords: ibuprofen; Vigna unguiculata; pharmaceutical pollutant; seed germination; plant growth; enzyme activities; IBU toxicity

\section{Introduction}

Pharmaceutical drug research focuses on how drugs affect target organs as well as ensuring the drug is persistent, retaining its chemical structure to perform the desired therapeutic effect [1]. However, the possible physiological and ecological effects of these compounds on nontarget species and ecosystems are largely unknown $[2,3]$. Therefore, the release of pharmaceutical compounds into the environment is of great concern for both environmental and human health [4]. Many pharmaceuticals used in human medical care are not completely reduced by the human body; more than $50 \%$ of the intake is excreted in feces or urine, entering the sewage system unchanged or slightly transformed [5]. Furthermore, many unused and expired drugs are directly discharged to the environment without any 
treatment due to a lack of standard protocols or regulatory policies for the disposal of pharmaceuticals, especially in the Middle East [6].

Ibuprofen is a nonsteroidal anti-inflammatory drug (NSAID) that is used to treat pain, common colds, fever, inflammation, migraines, and reduce human prostate cancer cell proliferation. Globally, approximately 44,347 metric tons of ibuprofen (IBU) was used in 2019 [7]. IBU represents one of the most widespread pharmaceuticals found in surface waters and sediments around the world. A growing human population and increasing health care trend have elevated the amount of consumed and expired IBU, leading to a steady increase of IBU in wastewaters. The compound may negatively affect humans, animals, microbes, and plants [8-13]. Although wastewater treatment plants can remove up to $80 \%$ of the IBU in water, a significant amount remains in the effluent, which can negatively impact the receiving environment [14]. Additionally, the repeated application of sewage sludge and use of reclaimed water for irrigation can also lead to the accumulation of IBU in agricultural areas. In Al-Hassa, Saudi Arabia, researchers found accumulated IBU at average concentrations of $0.5 \mathrm{ppb}$ in wastewater, $2.4 \mathrm{ppb}$ in sediment, $6 \mathrm{ppb}$ in soil, and $13.52 \mathrm{ppb}$ in plant samples $[15,16]$. Despite reports of IBU accumulation in the ecosystem, the ecotoxicological effects of IBU on plants have not been well studied.

Cowpea (Vigna unguiculata (L.) Walp.) is one of the most important food legumes in semi-arid regions of the tropics [17]. Over 14 million ha of agricultural land worldwide are occupied by cowpea, with a yearly production of $4.4 \mathrm{Mt}$ [18]. The fast growth, sensitivity, and developmental characteristics of cowpea make this crop a suitable organism for assessing the toxicological effects of pollutants. This study evaluates the effects of IBU on the vegetative stage of cowpea using a series of toxicity experiments.

\section{Results and Discussion}

Plants suffer from abiotic stress due to pollution and environment-related factors. Plants respond to stress in complex and marvelous ways, including morphological and physiological changes [19]. In $V$. unguiculata plants, growth and biomass reduction were the main outcomes of exposure to high concentrations of IBU (Figure $1 \mathrm{~A}-\mathrm{D}$ ). The $\mathrm{IC}_{50}$ value for biomass (IBU $1253 \mathrm{ppm}, R^{2} 0.948, p$-value $4.01 \times 10^{-17}$ ) and plant length (IBU $1955 \mathrm{ppm}, R^{2} 0.974, p$-value $6.20 \times 10^{-22}$ ) were calculated using regression. The shoot and root length, biomass weight, and total leaf area of IBU-treated plants decreased dose-dependently as a result of the IBU cytotoxic effect [20], chlorophyll breakdown [10], nutrient imbalance [21], and inhibition of cell division [11]. Other researchers have also reported severe reductions in the morphological parameters of Salix alba [22], Typha latifolia, Juncus effuses [23], and Phragmites australis [24] exposed to IBU stress. 


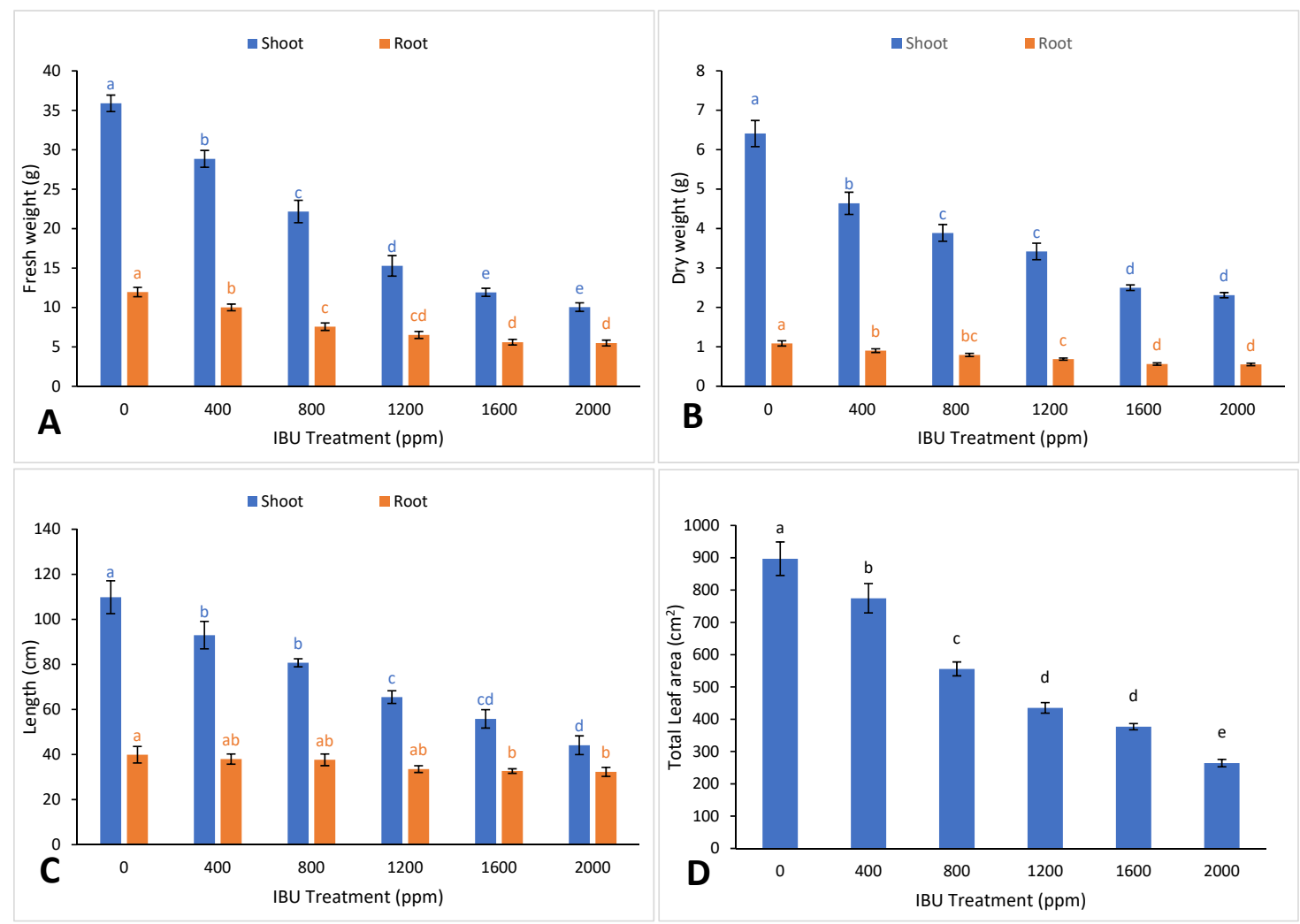

Figure 1. Effect of ibuprofen (IBU) treatments on (A) fresh weight, (B) dry weight, (C) length, and (D) leaf area of Vigna unguiculata on day 50. Different superscripts above the bars indicate significant differences at each measured time point $(p<0.05)$. All values are mean \pm SE of three replicates.

In the current study, IBU application induced a significant decline in chlorophyll a, chl b, total chlorophyll, and total carotenoid contents in V. unguiculata leaves (Figure 2A,B). The observed reduction in photosynthetic pigments may be attributed to several mechanisms, namely, the inhibition of biosynthesis or breakdown of pigments or their precursor molecules [24], reduction in photosynthetic activity in leaf quantum yield ФPSII [22], breakdown of the thylakoid and chloroplast envelope due to its lipophilic properties [24], and decreased leaf area [25,26]. The alteration of chlorophyll and carotenoid contents by IBU was previously reported by Moro et al. [10] in microalgae Scenedesmus rubescens, Iori et al. [22] in Salix alba, Kotyza et al. [24] in Phragmites australis, and Wrede [27] in Ceratophyllum demersum. 

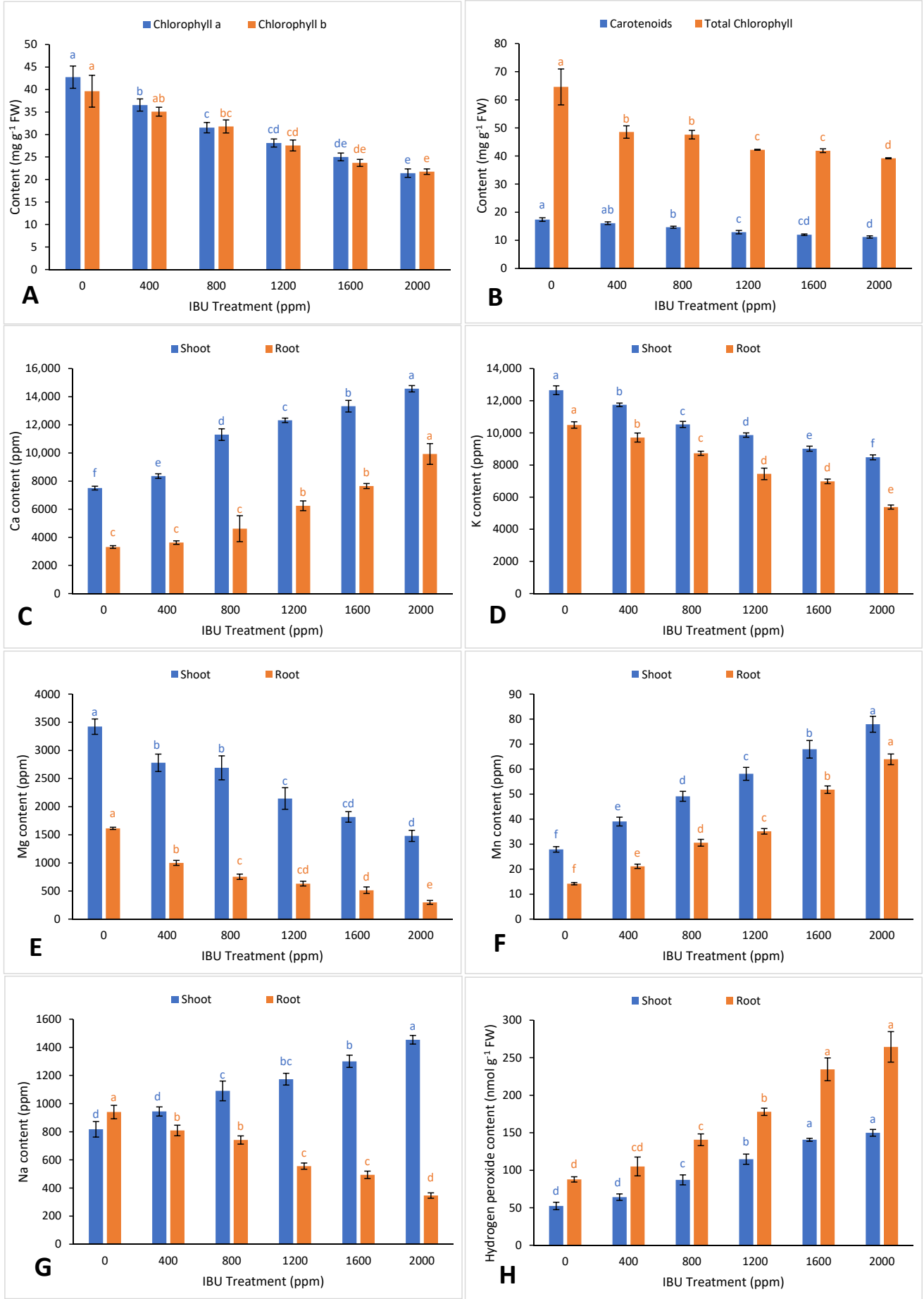

Figure 2. Effect of ibuprofen (IBU) treatments on (A) chl a and b, (B) car and total chl, (C) calcium, (D) potassium, (E) magnesium, (F) manganese, (G) sodium, and $(\mathbf{H}) \mathrm{H}_{2} \mathrm{O}_{2}$ in V. unguiculata on day 50. Different superscripts above the bars indicate significant differences at each measured time point $(p<0.05)$. All values are mean \pm SE of three replicates.

The application of IBU to V. unguiculata plants caused a nutrient imbalance (Figure 2C-G). Significant increases in calcium content were observed in the shoots and roots of the plants. Calcium plays a structural role within cells and signals plant responses such as osmotic regulation [28,29]. Disturbance in Ca balance (above 10,000 ppm) changes the photochemical phase and affects photosystem II (PSII), which reduces the stability and aggregation of chlorophyll molecules in the antenna 
complex [30], regulation of electron transport, and synthesis of NADP and ATP [31]. IBU also lowered the potassium content in the shoots and roots of $V$. unguiculata, which affects stomata regulation, transpiration, and osmoregulation [32]. IBU exposure reduced the magnesium content in the shoots and roots of V. unguiculata. Low magnesium inhibits nitrogen metabolism and reduces the photosynthesis rate due to slow light reaction in the stroma $[33,34]$, which causes reductions in biomass and photosynthesis and increases biochemical disorders [21]. In this study, IBU was shown to increase the accumulation of manganese in the shoots and roots of V. unguiculata. Excess Mn is toxic to the plant, which manifests as a reduction in biomass and photosynthesis and biochemical disorders such as oxidative stress [21]. Long-term treatment with IBU increased sodium translocation from the roots to shoots of $V$. unguiculata. Sodium accumulation in the shoots leads to early aging of adult leaves, reduction in the photosynthetic mechanism, and toxicity symptoms, which cease protein synthesis and interfere with enzyme regulation [35].

Pharmaceutical stress triggers an oxidative burst in subcellular compartments, especially in the mitochondria and chloroplasts, through the accumulation of reactive oxygen species (ROS). These ROS compounds have the ability to disrupt cell integrity by damaging lipids, proteins, and DNA, ultimately leading to cell death [36]. In the present study, IBU application increased hydrogen peroxide ROS content in V. unguiculata shoots and roots (Figure $2 \mathrm{H}$ ). Excess ROS in plants results in lipid peroxidation of the cell membrane, which produces malondialdehyde (MDA), a reactive mutagen and a marker of oxidative stress [37]. Increased MDA content in the shoots and roots of $V$. unguiculata plants was observed after IBU exposure (Figure 3A), indicating that the properties of IBU can cause oxidative damage. Our findings support previous reports by Almohisen [38] and Kummerová et al. [39], in which pharmaceutical applications resulted in oxidative stress, increasing $\mathrm{H}_{2} \mathrm{O}_{2}$ and MDA content in Vigna radiata and Lemna minor, respectively.

Excess ROS are scavenged by the enzymatic and nonenzymatic components of the plant-antioxidant defense system [40]. Some of the antioxidative enzymes that are directly involved in ROS detoxification are catalase (CAT), superoxide dismutase (SOD), ascorbate peroxidase (APX), glutathione peroxidase (GPX), and glutathione reductase (GR) [40]. Our results show that ibuprofen uptake leads to substantial increases in antioxidant activities, which contribute to plant stress tolerance. The activities of antioxidative enzymes SOD, CAT, APX, and GR were enhanced with exposure to IBU (Figure 3B-F). SOD accelerates the conversion of superoxide anion $\left(\mathrm{O}_{2}{ }^{-}\right)$into molecular oxygen $\left(\mathrm{O}_{2}\right)$ and $\mathrm{H}_{2} \mathrm{O}_{2}$ [41] . $\mathrm{H}_{2} \mathrm{O}_{2}$ is catalyzed by GPX, GR, CAT, and APX to convert it into non-toxic components such as oxygen, $\mathrm{H}_{2} \mathrm{O}$, and other alcohols [42]. Elevated antioxidant levels due to pharmaceutical stress were also documented in V. radiata [38], Typha ssp. [43], Populus alba [44], and Lemna minor [11,39]. The diminution of protein content in plants serves as a bioindicator of pollution in the environment [45]. In our study, the IBU treatments decreased the protein content of V. unguiculata (Figure 3G). This result may be attributed to an enhanced rate of protein denaturation caused by ROS activities and increased sodium content; the finding is consistent with the research of Hasan, et al. [46] and Munns [35]. The correlations between parameters are shown in the principal component analysis (PCA) biplot in Figure 4. The variables in group I and group II are significantly positively correlated to their own group and significantly negatively correlated with the opposite group. 

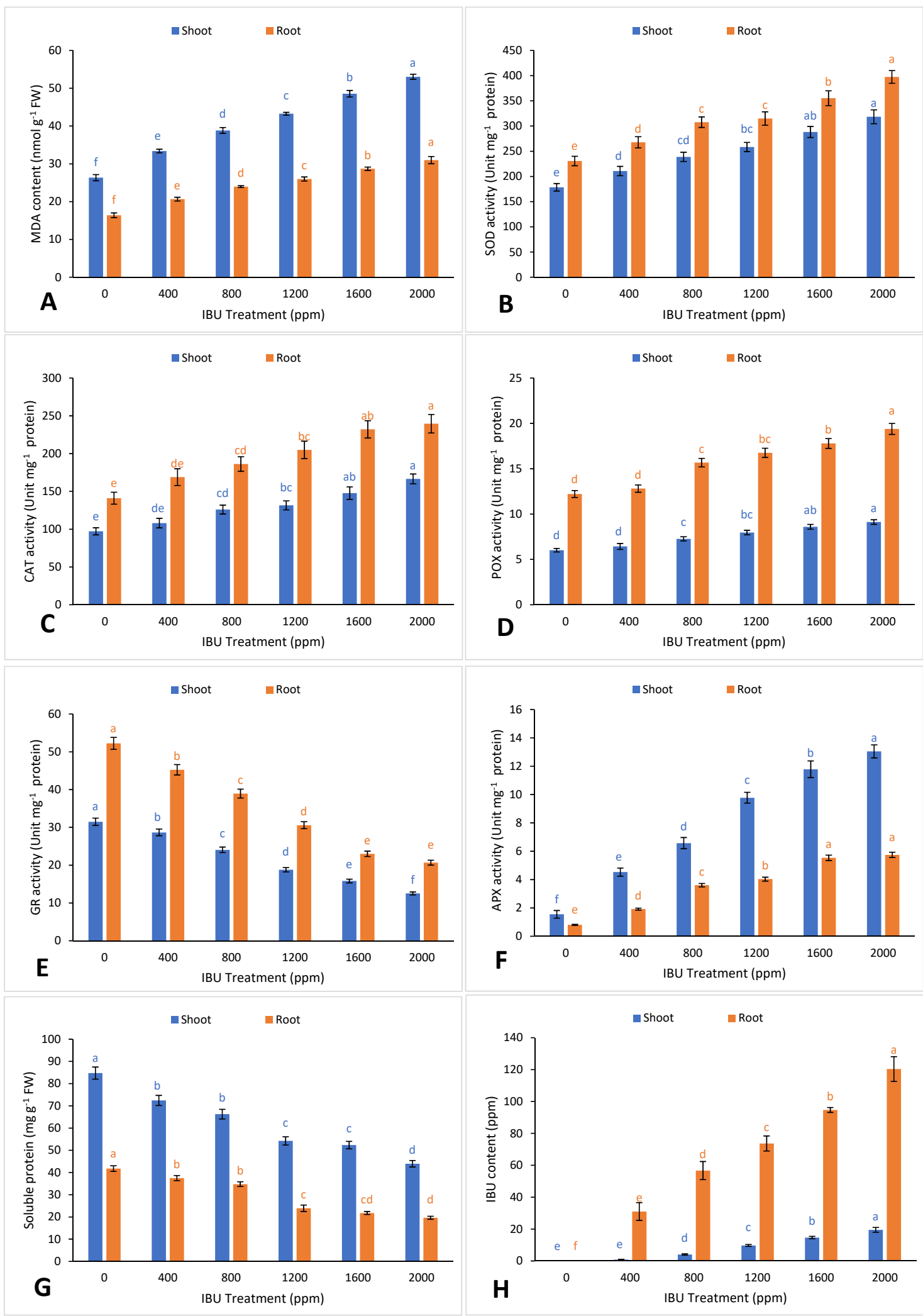

Figure 3. Effect of ibuprofen (IBU) treatments on (A) malondialdehyde (MDA), (B) superoxide dismutase (SOD), (C) catalase (CAT), (D) peroxidase (POX), (E) glutathione reductase (GR), (F) Soluble protein, (G) ascorbate peroxidase (APX), and (H) IBU content in V. unguiculata on day 50. Different superscripts above the bars indicate significant differences at each measured time point $(p<0.05)$. All values are mean \pm SE of three replicates. 


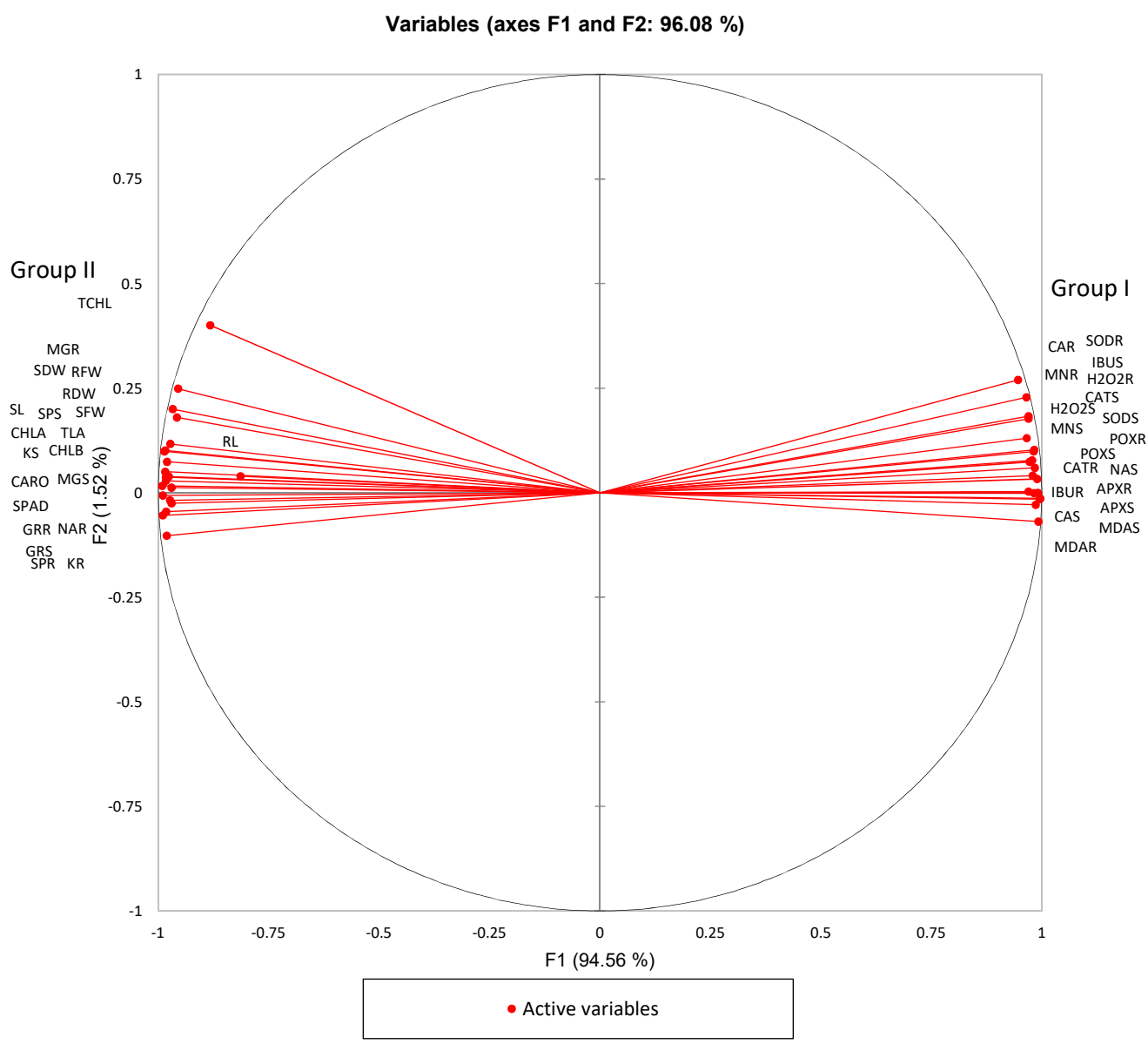

Figure 4. PCA (principal component analysis) of IBU effects on V. unguiculata. SL, shoot length; RL, root length; SFW, shoot fresh weight; SDW, shoot dry weight; RFW, root fresh weight; RDW, root dry weight; TLA, total leaf area; SPAD, leaf SPAD; CHLA, chlorophyll a; CHLB, chlorophyll b; CARO, total carotenoids; TCHL, total chlorophyll; CAS, shoot calcium; CAR, root calcium; KS, shoot potassium; KR, root potassium; MGS, shoot magnesium; MGR, root magnesium; MNS, shoot manganese; MNR, root manganese; NAS, shoot sodium; NAR, root sodium; $\mathrm{H} 2 \mathrm{O} 2 \mathrm{~S}$, shoot $\mathrm{H}_{2} \mathrm{O}_{2} ; \mathrm{H} 2 \mathrm{O} 2 \mathrm{R}$, root $\mathrm{H}_{2} \mathrm{O}_{2}$; MDAS, shoot MDA; MDAR, root MDA; SODS, shoot SOD; SODR, root SOD; CATS, shoot CAT; CATR, root CAT; POXS, shoot POX; POXR, root POX; GRS, shoot GR; GRR, root GR; SPS, shoot soluble protein; SPR, root soluble protein; APXS, shoot APX; APXR, root APX; IBUS, shoot ibuprofen; IBUR, root ibuprofen.

IBU is a microcontaminant with relatively high solubility and intermediate hydrophobicity [47], these properties facilitate its mobility in wastewaters and its potential uptake by plants and translocation into the xylem and phloem $[47,48]$. In the present study, we found that IBU uptake by $V$. unguiculata progressively enhanced with increasing concentrations of IBU (Figure 3H). Low levels of IBU were bioconcentrated in the roots $(6-7 \%)$ and shoots $(0.2-0.9 \%)$ of $V$. unguiculata compared to the IBU concentration in the media. The amount of bioaccumulated IBU varied between $7 \%$ and $8 \%$ (Table 1 ). IBU was transported upward from the medium to the seeds and further translocated through roots to shoots with a translocation factor between $3 \%$ and $16 \%$. Plants can take up, translocate, and degrade IBU by transforming IBU to eight phase-I and 38 Phase-II metabolites in the intercellular compartments, storing those compounds in the vacuoles or cell walls [26]. The uptake and metabolization of IBU to IBU-hydroxylated derivatives was also observed in V. unguiculata [26], Lemna gibba [49], and Phragmites australis [50]. 
Table 1. The bioconcentration factor (BCF), bioaccumulation factor (BAF), and translocation factor (TF) of ibuprofen (IBU) in $V$. unguiculata plants on day 50.

\begin{tabular}{ccccc}
\hline & \multicolumn{2}{c}{$\begin{array}{c}\text { Bioconcentration Factor } \\
\text { (BCF) }\end{array}$} & $\begin{array}{c}\text { Bioaccumulation Factor } \\
\text { (BAF) }\end{array}$ & $\begin{array}{c}\text { Translocation Factor } \\
\text { (TF) }\end{array}$ \\
\hline $\begin{array}{c}\text { IBU Treatments } \\
\text { (ppm) }\end{array}$ & Roots & Shoots & Whole Plants & From Roots to Shoots \\
\hline 400 & 0.078 & 0.002 & 0.08 & 0.029 \\
800 & 0.071 & 0.005 & 0.076 & 0.072 \\
1200 & 0.061 & 0.008 & 0.07 & 0.132 \\
1600 & 0.059 & 0.009 & 0.068 & 0.155 \\
2000 & 0.06 & 0.01 & 0.07 & 0.162 \\
\hline
\end{tabular}

\section{Materials and Methods}

\subsection{Plant Growth Experiment}

V. unguiculata L. seeds were surface sterilized using a diluted hypochlorite solution (1:10 dilution of Clorox-R and water V/V) for $20 \mathrm{~min}$, rinsed repeatedly with distilled water, and then air-dried for one hour. The seeds were sown in a tray filled with perlite. After 10 days, the seedlings were transplanted into pots (Polyvinyl chloride pots; $15 \mathrm{~cm}$ diameter, $15 \mathrm{~cm}$ depth) filled with perlite. Plants were sown at a density of one seedling per pot with three replicates per treatment, including the control (acid-washed sand). The seedlings were irrigated thrice per week with a graduated treatment regimen $(0,400,800,1200,1600,2000 \mathrm{ppm}$ IBU) throughout the experiment. Additional water with $300 \mathrm{~mL}$ of full-strength Hoagland nutrient solution was provided on alternate days to ensure adequate nutrition. In the growth chamber, photosynthetically active radiation $\left(67-170 \mu \mathrm{moL} \mathrm{m}^{-2} \mathrm{~s}^{-1}\right)$ was provided on a 14:10 light/dark cycle; temperature (day $26^{\circ} \mathrm{C}$, night $20^{\circ} \mathrm{C}$ ) and relative humidity $( \pm 45 \%$ ) was maintained throughout the experiment. The plants were sampled at 50 days after transplantation to assess the selected growth, morphological, and physicochemical parameters.

Length, fresh and dry weight of shoots and roots were measured at the sampling time [51]. The total leaf area (LA) of each plant was determined using an automatic leaf area meter (CI-202 area meter, CID, Inc., Camas, WA, USA).

\subsection{Physicochemical Analysis}

\subsubsection{Chlorophyll and Carotenoid}

The chlorophyll (Chl) and carotenoid (Car) contents of leaves were measured and calculated following the method described by Lichtenthaler and Welburn [52], Porra [53]. A mortar and pestle were used to grind $0.1 \mathrm{~g}$ of fresh leaf with $80 \%$ acetone to extract the pigments. The extracts were passed through filter paper and the absorbance of each sample was measured at 663, 646, and $470 \mathrm{~nm}$ using an ultraviolet-visible spectrophotometer (UV-1800, Shimadzu, Columbia, MD, USA). Chlorophyll a, b, carotenoid, and total chlorophyll contents were calculated using the following equations.

$$
\begin{gathered}
\text { Chla }=12.21 A 663-2.81 A 646 \\
\text { Chlb }=20.13 A 646-5.03 A 663 \\
\text { Car }=\frac{1000 A 470-3.27 C h l a-104 C h l b}{229} \\
\text { Total Chl }=17.76 A 646+7.34 A 663
\end{gathered}
$$




\subsection{2. $\mathrm{Ca}, \mathrm{K}, \mathrm{Mg}, \mathrm{Mn}$, and $\mathrm{Na}$ Content}

The experiment samples were prepared according to standard digestion procedures for plant materials [54]. In brief, $200 \mathrm{mg}$ of finely ground seedling samples was added to a $100 \mathrm{~mL}$ TECAM digestion flask with $0.5 \mathrm{~mL}$ of sulfuric acid, $1 \mathrm{~mL}$ of perchloric acid, and $5 \mathrm{~mL}$ of nitric acid. The flasks were heated at $110^{\circ} \mathrm{C}$, gradually increasing to a final temperature of $330^{\circ} \mathrm{C}$. After cooling, the solution was transferred to a $50 \mathrm{~mL}$ calibrated flask and filled to volume with double distilled water. Standard elements were prepared, and $\mathrm{Ca}, \mathrm{K}, \mathrm{Mg}, \mathrm{Mn}$, and $\mathrm{Na}$ content were measured using a Perkin Elmer AAS-300 atomic absorption spectrophotometer according to Katz and Jennis [55].

\subsubsection{Hydrogen Peroxide Content}

Hydrogen peroxide levels were determined following the method of Velikova et al. [56]. Plant tissues $(100 \mathrm{mg})$ were homogenized in an ice bath with $5 \mathrm{~mL} 0.1 \%(w / v)$ trichloroacetic acid (TCA). The homogenates were centrifuged at $12,000 \mathrm{rpm}$ for $15 \mathrm{~min}$. Next, $0.5 \mathrm{~mL}$ of the supernatant was added to $0.5 \mathrm{~mL}$ of $10 \mathrm{mM}$ potassium phosphate buffer (pH 7.0) and $1 \mathrm{~mL}$ of $1 \mathrm{M} \mathrm{KI}$. The absorbance was measured at $390 \mathrm{~nm}$. The $\mathrm{H}_{2} \mathrm{O}_{2}$ content is presented on a standard curve and expressed as nmol g-1 FW.

\subsubsection{Malondialdehyde (MDA) Assay}

The level of lipid peroxidation was determined by measuring 2-thiobarbituric acid-reactive metabolites, mainly MDA, following the modified method by Heath and Packer [57]. Frozen $100 \mathrm{mg}$ samples were homogenized in a pre-chilled mortar and pestle with two volumes of ice-cold $0.1 \%$ $(w / v)$ trichloroacetic acid (TCA) and centrifuged for $15 \mathrm{~min}$ at 15,000 rpm. The $3 \mathrm{~mL}$ assay mixture containing $1 \mathrm{~mL}$ of supernatant and $2 \mathrm{~mL}$ of $0.5 \%(w / v)$ thiobarbituric acid in $20 \%(w / v)$ TCA was heated to $95^{\circ} \mathrm{C}$ for $30 \mathrm{~min}$ and then rapidly cooled in an ice bath. After centrifugation (10,000 rpm for $10 \mathrm{~min}$ at $\left.4{ }^{\circ} \mathrm{C}\right)$, the supernatant absorbance $(\lambda=532 \mathrm{~nm})$ was read and the values corresponding to non-specific absorption $(\lambda=600 \mathrm{~nm})$ were subtracted. MDA concentration was calculated using the following equation with an extinction coefficient of $155 \mathrm{mM}^{-1} \mathrm{~cm}^{-1}$.

$$
M D A \text { content }(m M)=\frac{\left(A_{532}-A_{600}\right)}{155} \times \text { vol of reaction mixture }
$$

\subsubsection{Enzyme Activity and Soluble Protein}

Enzymes were extracted using the Beauchamp and Fridovich [58] method. A $0.1 \mathrm{~g}$ sample of plant material was ground with $100 \% w / w$ insoluble polyvinyl-polypyrrolidone in $1 \mathrm{~mL}$ of extraction buffer $\left(\mathrm{KH}_{2} \mathrm{PO}_{4} / \mathrm{K}_{2} \mathrm{HPO}_{4} 66 \mathrm{mM}\right.$; ethylenediaminetetraacetic acid (EDTA), $1 \mathrm{mM} ; \mathrm{pH}$ 7). To extract ascorbate and glutathione, sample material $(0.1 \mathrm{~g})$ was ground in $1 \mathrm{~mL}$ of $6 \% w / v$ metaphosphoric acid containing $1 \mathrm{mM}$ EDTA. The homogenate was centrifuged $(10,000 \mathrm{~g})$ for $3 \mathrm{~min}$ at $4{ }^{\circ} \mathrm{C}(3 \mathrm{~K}-18$ centrifuge, Sigma, Osterode am Harz, Germany). Residual leaf extracts were decanted into fresh Eppendorf tubes for subsequent analysis. Superoxide dismutase (SOD) activity was assayed by measuring the ability of the enzyme extract to inhibit the photochemical reduction of nitroblue tetrazolium (NBT) to purple formazan, measured spectrophotometrically at $560 \mathrm{~nm}$. Enzyme extract $(0.1 \mathrm{~mL})$ was added to the reaction mixture of $2.9 \mathrm{~mL} 50 \mathrm{mM} \mathrm{K}$ phosphate buffer (pH 7.8), containing $10 \mathrm{mM}$ methionine, $168 \mu \mathrm{M}$ NBT, $0.025 \%$ Triton $X-100$, and $1.17 \mu \mathrm{M}$ riboflavin, for a total volume of $3 \mathrm{~mL}$. The assay was placed in a test tube under yellow light for $15 \mathrm{~min}$. The amount of methionine-mediated formazan formed (At) was compared with the amount of formazan formed in the absence of the enzyme (Ac). One unit of SOD is defined as the quantity that causes $50 \%$ inhibition of formazan formation. The activity was expressed as Unit activity $\left(\mathrm{U} \mathrm{mL}^{-1}\right)$ [58].

$$
\operatorname{SOD} \operatorname{Activity}\left(\mathrm{U} \mathrm{mL}^{-1}\right)=\frac{A c-A t}{A c \times 0.5}
$$




$$
\text { Specific activity }(\mathrm{UA} / \mathrm{g} \text { Protein })=\frac{\text { Unit activity }(\mathrm{U} / \mathrm{min} / \mathrm{g} \text { Fresh Weight })}{\text { Protein } \operatorname{content}(\mathrm{mg} / \mathrm{g} \text { Fresh Weight })}
$$

The estimation of catalase activity was performed according to the method of Aebi [59]. The assay contained $66 \mathrm{mM} \mathrm{KH}_{2} \mathrm{PO}_{4} / \mathrm{K}_{2} \mathrm{HPO}_{4}\left(\mathrm{pH}\right.$ 7), $35 \mathrm{mM} \mathrm{H}_{2} \mathrm{O}_{2}$, and $20 \mu \mathrm{L}$ extract. Catalase activity (CAT) was determined from the decline in absorbance at $240 \mathrm{~nm}$ and $25{ }^{\circ} \mathrm{C}$, following $\mathrm{H}_{2} \mathrm{O}_{2}$ breakdown. The quantity of enzyme necessary to release half the peroxide oxygen from hydrogen peroxide represents one unit of catalase activity. An extinction coefficient of $39.4 \mathrm{mM}^{-1} \mathrm{~cm}^{-1}$ for $\mathrm{H}_{2} \mathrm{O}_{2}$ at $240 \mathrm{~nm}$ was used to calculate the activity of catalase using the following formulas.

$$
\text { Unit activity }\left(\frac{\frac{\mathrm{U}}{\mathrm{min}}}{\mathrm{g}} \text { Fresh Weight }\right)=\frac{\text { Change in } \frac{\text { absorbance }}{\mathrm{minTotalvolume}}(\mathrm{mL})}{\varepsilon \times \text { Volume of sample used }(\mathrm{mL}) \times \text { Fresh Weight of sample }},
$$

where $\varepsilon$ represents extinction coefficient $=39.4 \mathrm{mM}^{-1} \mathrm{~cm}^{-1}$.

$$
\text { Specific activity }(\mathrm{UA} / \mathrm{g} \text { Protein })=\frac{\text { Unit activity }(\mathrm{U} / \mathrm{min} / \mathrm{g} \text { Fresh Weight })}{\text { Protein content }(\mathrm{mg} / \mathrm{g} \text { Fresh Weight })}
$$

Peroxidase was assayed following the method of Tiedemann [60]. The reagent mixture contained $0.05 \%$ guaiacol $\left(440 \mu \mathrm{L}^{-1}\right)$ and $10 \mathrm{mM} \mathrm{H}_{2} \mathrm{O}_{2}$ dissolved in $25 \mathrm{~mL}$ sodium phosphate buffer ( $\mathrm{pH} 7$ ). Crude enzyme extracts $(20 \mu \mathrm{L})$ and $200 \mu \mathrm{L}$ reagent mixture were transferred into 96-well microtiter plates, then incubated for $10 \mathrm{~min}$ at room temperature in the dark. The absorbance of the brown guaiacol reaction was immediately measured at $450 \mathrm{~nm}$, as described above. As the incubation time, sample volumes, and leaf disk areas were equal in all samples, the peroxidase (POX) activities of different samples were expressed as absorbance units (absorbances $\times 1000)$ and compared directly. POX activities were expressed as absorbance $\mathrm{g}^{-1} \mathrm{FW}$.

Glutathione reductase (GR, EC1.6.4.2) was assayed by measuring the change in absorbance at $340 \mathrm{~nm}$ following the oxidation of reduced Nicotinamide adenine dinucleotide phosphate (NADPH) [61]. The reaction mixture contained $100 \mathrm{mM}$ potassium phosphate buffer ( $\mathrm{pH} 7.0)$, $1.0 \mathrm{mM}$ EDTA, $50 \mu \mathrm{M}$ NADPH, $100 \mu \mathrm{M}$ oxidized glutathione, and $100 \mu \mathrm{L}$ enzyme in a final volume of $3 \mathrm{~mL}$. GR activity was expressed as $\mathrm{U} \mathrm{mg}^{-1}$ protein. The decrease in absorbance per minute was observed at intervals of $3 \mathrm{~s}$ at $340 \mathrm{~nm}$ and $25^{\circ} \mathrm{C}$. One unit of GR enzyme activity is defined as the amount of enzyme required to oxidize $1.0 \mu \mathrm{M}$ of NADPH min $^{-1} \mathrm{~g}^{-1} \mathrm{FW}$. The unit activity and specific activity were calculated using the following formulas.

$$
\text { Unit activity }\left(\frac{\frac{\mathrm{U}}{\mathrm{min}}}{\mathrm{g}} \text { Fresh Weight }\right)=\frac{\text { Change in } \frac{\text { absorbance }}{\mathrm{minTotalvolume}}(\mathrm{mL})}{\varepsilon \times \text { Volume of sample used }(\mathrm{mL}) \times \text { Fresh Weight of sample }}
$$

where $\varepsilon$ represents extinction coefficient $=6.22 \mathrm{mM}^{-1} \mathrm{~cm}^{-1}$.

$$
\text { Specific activity }(\mathrm{UA} / \mathrm{g} \text { Protein })=\frac{\text { Unit activity }(\mathrm{U} / \mathrm{min} / \mathrm{g} \text { Fresh Weight })}{\text { Protein content }(\mathrm{mg} / \mathrm{g} \text { Fresh Weight })}
$$

Ascorbate peroxidase (APX) activity was determined from the decrease in absorbance measured at $290 \mathrm{~nm}$, following the consumption of ascorbic acid (AA) [62]. APX activity was calculated using an extinction coefficient of $2.8 \mathrm{mM}^{-1} \mathrm{~cm}^{-1}$ for AA at $290 \mathrm{~nm}$.

Soluble proteins were assayed according to the method of Bradford [63] using bovine serum albumin as a standard and related to plant dry weight. Leaf samples $(0.1 \mathrm{~g})$ were ground using $3 \mathrm{~mL}$ of $50 \mathrm{mM}$ potassium phosphate buffer with $\mathrm{pH} 7.0$ phosphate buffer in an ice bath. The homogenates were centrifuged for $20 \mathrm{~min}$ at $13,000 \mathrm{rpm}$ and $4{ }^{\circ} \mathrm{C}$. Then, $0.1 \mathrm{~mL}$ of the supernatants was treated with $2 \mathrm{~mL}$ of Bradford reagent (50 mg of Coomassie Brilliant Blue G-250 in $50 \mathrm{~mL}$ of methanol, $100 \mathrm{~mL}$ 
$85 \%(w / v)$ phosphoric acid $\left(\mathrm{H}_{3} \mathrm{PO}_{4}\right)$, and $850 \mathrm{~mL}$ of distilled water) and incubated for $5 \mathrm{~min}$ before absorbance was measured at $595 \mathrm{~nm}$.

\subsubsection{Ibuprofen Analysis}

The extraction, separation, concentration, and validation of IBU from experiment samples were analyzed according to Picó et al. [26] and Andreotti et al. [64] using ultra-high performance liquid chromatography (Agilent 1260 Infinity, Waldbronn, Germany) and an AB SCIEX TripleTOFTM 5600 mass spectrometer (AB SCIEX, Foster City, CA, USA). Data acquisition processing and instrument control were performed using Analyst, Peak View 1.0, and MultiQuant 2.0. software [26].

The bioconcentration factor (BCF), bioaccumulation factor (BAF), and translocation factor (TF) of IBU in V. unguiculata plants were calculated according to Wang [65]:

$$
\begin{gathered}
B C F(\mathrm{~L} / \mathrm{Kg})=\frac{I B U \text { concentration in media }(\mathrm{mg} / \mathrm{L})}{I B U \text { concentration in plant tissue }(\mathrm{mg} / \mathrm{Kg})}, \\
B C F(\mathrm{~L} / \mathrm{Kg})=\frac{I B U \text { concentration in media }(\mathrm{mg} / \mathrm{L})}{I B U \text { concentration in whole plant tissue }(\mathrm{mg} / \mathrm{Kg})}, \\
T F=\frac{I B U \text { concentration in shoot }(\mathrm{mg} / \mathrm{Kg})}{I B U \text { concentration in root }(\mathrm{mg} / \mathrm{Kg})} .
\end{gathered}
$$

\subsection{Statistical Analysis}

All experimental data were analyzed by one-way analysis of variance with the Bonferroni correction for multiple comparisons $(p<0.05)$ using statistical software package STATISTIX 10 (Analytical Sofware, Tallahassee, FL, USA). Regression was analyzed using PASW Statistics 18 (IBM, New York, NY, USA). Principal Component Analysis (PCA) was performed using XLstat (Addinsoft, New York, NY, USA). Graphics were produced using Microsoft Excel.

\section{Conclusions}

Vigna unguiculata plants develop several morphological and physicochemical adaptations to cope with ibuprofen stress. The ecotoxicological effects of IBU on plant growth consist of decreased plant length, biomass, LA, chlorophyll and carotenoid biosynthesis, impaired mineral balance, and lowered total protein. IBU uptake increased the levels of ROS such as $\mathrm{H}_{2} \mathrm{O}_{2}$, which were alleviated through increased synthesis of antioxidant enzymes such as SOD, CAT, POX, GR, and APX. According to the IC50 values for biomass (IBU 1253 ppm) and plant length (IBU 1955 ppm) observed in this study, we concluded that the current range of IBU environmental pollution $(0.5-6 \mathrm{ppb})$ would have minimal effect on $V$. unguiculata. For future research possibilities, it would be interesting to study IBU effects on the anatomy of the plant, the location of metabolite degradation, and immobilization in cell components, the promotion of growth by low concentrations of IBU, and the genetic mechanism that controls the transformation of IBU metabolites in the plant.

Author Contributions: Conceptualization, M.A. and L.W.; methodology, P.A.; software, L.W.; validation, Y.P., D.B. and L.W.; formal analysis, L.W., Y.P. and D.B.; investigation, L.W.; resources, D.B., A.A., M.A., M.A.E.-S.; data curation, L.W., Y.P.; writing—original draft preparation, L.W.; writing-review and editing, P.A.; visualization, L.W.; supervision, M.A.; project administration, A.A. All authors have read and agreed to the published version of the manuscript.

Funding: This research was funded by the Deanship of Scientific Research at King Saud University, grant number RGP-199.

Acknowledgments: The authors would like to extend their sincere appreciation to the Deanship of Scientific Research at King Saud University for its funding Research group No. (RGP-199). The authors thank the Deanship of Scientific Research and RSSU at King Saud University for their technical support.

Conflicts of Interest: The authors declare no conflict of interest. 


\section{References}

1. Torchilin, V.P. Drug targeting. Eur. J. Pharm. Sci. 2000, 11, S81-S91. [CrossRef]

2. Ellis, J.B. Pharmaceutical and personal care products (PPCPs) in urban receiving waters. Environ. Pollut. 2006, 144, 184-189. [CrossRef] [PubMed]

3. Vatovec, C.; Van Wagoner, E.; Evans, C. Investigating sources of pharmaceutical pollution: Survey of over-the-counter and prescription medication purchasing, use, and disposal practices among university students. J. Environ. Manag. 2017, 198, 348-352. [CrossRef] [PubMed]

4. Li, W.C. Occurrence, sources, and fate of pharmaceuticals in aquatic environment and soil. Environ. Pollut. 2014, 187, 193-201. [CrossRef]

5. Tiwari, B.; Sellamuthu, B.; Ouarda, Y.; Drogui, P.; Tyagi, R.D.; Buelna, G. Review on fate and mechanism of removal of pharmaceutical pollutants from wastewater using biological approach. Bioresour. Technol. 2017, 224, 1-12. [CrossRef]

6. Shaaban, H. Pharmaceutical pollution: Perception and management. IJCST 2017, 105. [CrossRef]

7. Beroe-Inc. Ibuprofen Market Intelligence; Beroe Inc.: Raleigh, NC, USA, 2019.

8. González-Naranjo, V.; Boltes, K.; Biel, M. Mobility of ibuprofen, a persistent active drug, in soils irrigated with reclaimed water. Plant Soil Environ. 2013, 59, 68-73. [CrossRef]

9. Holling, C.S.; Bailey, J.L.; Heuvel, B.V.; Kinney, C.A. Uptake of human pharmaceuticals and personal care products by cabbage (Brassica campestris) from fortified and biosolids-amended soils. J. Environ. Monit. 2012, 14, 3029-3036. [CrossRef]

10. Moro, I.; Matozzo, V.; Piovan, A.; Moschin, E.; Vecchia, F. Morpho-physiological effects of ibuprofen on Scenedesmus rubescens. Environ. Toxicol. Pharmacol. 2014, 38, 379-387. [CrossRef]

11. Pomati, F.; Netting, A.G.; Calamari, D.; Neilan, B.A. Effects of erythromycin, tetracycline and ibuprofen on the growth of Synechocystis sp. and Lemna minor. Aquatic Toxicol. 2004, 67, 387-396. [CrossRef]

12. Maamar, M.B.; Lesné, L.; Hennig, K.; Desdoits-Lethimonier, C.; Kilcoyne, K.R.; Coiffec, I.; Rolland, A.D.; Chevrier, C.; Kristensen, D.M.; Lavoué, V. Ibuprofen results in alterations of human fetal testis development. Sci. Rep. 2017, 7, 44184. [CrossRef]

13. Xia, L.; Zheng, L.; Zhou, J.L. Effects of ibuprofen, diclofenac and paracetamol on hatch and motor behavior in developing zebrafish (Danio rerio). Chemosphere 2017, 182, 416-425. [CrossRef]

14. Březinova, T.D.; Vymazal, J.; Koželuh, M.; Kule, L. Occurrence and removal of ibuprofen and its metabolites in full-scale constructed wetlands treating municipal wastewater. Ecol. Eng. 2018, 120, 1-5. [CrossRef]

15. Picó, Y.; Alvarez-Ruiz, R.; Alfarhan, A.H.; El-Sheikh, M.A.; Alshahrani, H.O.; Barceló, D. Pharmaceuticals, pesticides, personal care products and microplastics contamination assessment of Al-Hassa irrigation network (Saudi Arabia) and its shallow lakes. Sci. Total Environ. 2020, 701, 135021. [CrossRef] [PubMed]

16. Alshahrani, H. Evaluation of Ecological Pollution by Pesticides, Pharmaceuticals and Microplastics in Al-Hassa Lakes, Saudi Arabia; King Saud University: Riyadh, Saudi Arabia, 2020.

17. Ehlers, J.D.; Hall, A.E. Cowpea (Vigna unguiculata L. Walp.). Field Crops Res. 1997, 53, 187-204. [CrossRef]

18. Timko, M.P.; Ehlers, J.D.; Roberts, P.A. Cowpea. In Pulses, Sugar and Tuber Crops; Springer: Berlin/Heidelberg, Germany, 2007; pp. 49-67.

19. Atkinson, N.J.; Urwin, P.E. The interaction of plant biotic and abiotic stresses: From genes to the field. J. Exp. Bot. 2012, 63, 3523-3543. [CrossRef] [PubMed]

20. Kumar, V.L.; Singhal, A. Germinating seeds of the mung bean, Vigna radiata (Fabaceae), as a model for the preliminary evaluation of cytotoxic effects of drugs. Biocell 2009, 33, 19-24. [CrossRef]

21. Millaleo, R.; Reyes-Díaz, M.; Ivanov, A.; Mora, M.; Alberdi, M. Manganese as essential and toxic element for plants: Transport, accumulation and resistance mechanisms. J. Soil Sci. Plant Nutr. 2010, 10, 470-481. [CrossRef]

22. Iori, V.; Zacchini, M.; Pietrini, F. Growth, physiological response and phytoremoval capability of two willow clones exposed to ibuprofen under hydroponic culture. J. Hazard. Mater. 2013, 262, 796-804. [CrossRef]

23. Zhang, L.; Lv, T.; Zhang, Y.; Stein, O.R.; Arias, C.A.; Brix, H.; Carvalho, P.N. Effects of constructed wetland design on ibuprofen removal-A mesocosm scale study. Sci. Total Environ. 2017, 609, 38-45. [CrossRef]

24. Kotyza, J.; Soudek, P.; Kafka, Z.; Vaněk, T. Phytoremediation of Pharmaceuticals-Preliminary Study. Int. J. Phytoremediat. 2010, 12, 306-316. [CrossRef] 
25. Mohamed, H.I.; Akladious, S.A. Changes in antioxidants potential, secondary metabolites and plant hormones induced by different fungicides treatment in cotton plants. Pestic. Biochem. Physiol. 2017, 142, 117-122. [CrossRef]

26. Picó, Y.; Alvarez-Ruiz, R.; Wijaya, L.; Alfarhan, A.; Alyemeni, M.; Barceló, D. Analysis of ibuprofen and its main metabolites in roots, shoots, and seeds of cowpea (Vigna unguiculata L. Walp) using liquid chromatography-quadrupole time-of-flight mass spectrometry: Uptake, metabolism, and translocation. Anal. Bioanal. Chem. 2018, 410, 1163-1176. [CrossRef] [PubMed]

27. Wrede, J. Pharmaceutically Active Compounds Might Bioaccumulate and Cause Effects on the Free-Floating Macrophyte; Humboldt-Universität zu Berlin: Berlin, Germany, 2015.

28. Liu, Y.-F.; Han, X.-R.; Zhan, X.-M.; Yang, J.-F.; Wang, Y.-Z.; Song, Q.-B.; Chen, X. Regulation of calcium on peanut photosynthesis under low night temperature stress. J. Integr. Agric. 2013, 12, 2172-2178. [CrossRef]

29. Maathuis, F.J.; Diatloff, E. Roles and functions of plant mineral nutrients. In Plant Mineral Nutrients; Springer: Berlin/Heidelberg, Germany, 2013; pp. 1-21.

30. Ramalho, J.C.; Rebelo, M.; Santos, M.E.; Antunes, M.L.; Nunes, M.A. Effects of calcium deficiency on Coffea arabica. Nutrient changes and correlation of calcium levels with some photosynthetic parameters. Plant Soil 1995, 172, 87-96. [CrossRef]

31. Hochmal, A.K.; Schulze, S.; Trompelt, K.; Hippler, M. Calcium-dependent regulation of photosynthesis. Biochim. Biophys. Acta (BBA) Bioenerg. 2015, 1847, 993-1003. [CrossRef]

32. Mahouachi, J.; Socorro, A.R.; Talon, M. Responses of papaya seedlings (Carica papaya L.) to water stress and re-hydration: Growth, photosynthesis and mineral nutrient imbalance. Plant Soil 2006, 281, 137-146. [CrossRef]

33. Zhao, H.; Zhou, Q.; Zhou, M.; Li, C.; Gong, X.; Liu, C.; Qu, C.; Wang, L.; Si, W.; Hong, F. Magnesium deficiency results in damage of nitrogen and carbon cross-talk of maize and improvement by cerium addition. Biol. Trace Elem. Res. 2012, 148, 102-109. [CrossRef]

34. Liu, M.; Liu, X.X.; He, X.L.; Liu, L.J.; Wu, H.; Tang, C.X.; Zhang, Y.S.; Jin, C.W. Ethylene and nitric oxide interact to regulate the magnesium deficiency-induced root hair development in Arabidopsis. New Phytol. 2017, 213, 1242-1256. [CrossRef]

35. Munns, R. Comparative physiology of salt and water stress. Plant Cell Environ. 2002, 25, 239-250. [CrossRef]

36. Ahmad, P.; Sarwat, M.; Sharma, S. Reactive oxygen species, antioxidants and signaling in plants. J. Plant Biol. 2007, 51, 167-173. [CrossRef]

37. Del Rio, D.; Stewart, A.J.; Pellegrini, N. A review of recent studies on malondialdehyde as toxic molecule and biological marker of oxidative stress. Nutr. Metab. Cardiovasc. Dis. 2005, 15, 316-328. [CrossRef] [PubMed]

38. Almohisen, I.A. Effect of paracetamol on antioxidant system and osmoprotectants of mung bean (Vigna radiata). Appl. Ecol. Environ. Res. 2019, 17, 4297-4303. [CrossRef]

39. Kummerová, M.; Zezulka, Š.; Babula, P.; Tř́iska, J. Possible ecological risk of two pharmaceuticals diclofenac and paracetamol demonstrated on a model plant Lemna minor. J. Hazard. Mater. 2016, 302, 351-361. [CrossRef]

40. Ahmad, P.; Jaleel, C.A.; Salem, M.A.; Nabi, G.; Sharma, S. Roles of enzymatic and nonenzymatic antioxidants in plants during abiotic stress. Crit. Rev. Biotechnol. 2010, 30, 161-175. [CrossRef] [PubMed]

41. Bowler, C.; Van Camp, W.; Van Montagu, M.; Inze, D.; Asada, K. Superoxide dismutase in plants. Crit. Rev. Plant Sci. 1994, 13, 199-218. [CrossRef]

42. Carvalho, L.C.; Vidigal, P.; Amancio, S. Oxidative stress homeostasis in grapevine (Vitis vinifera L.). Front. Environ. Sci. 2015, 3. [CrossRef]

43. Bartha, B.; Huber, C.; Schröder, P. Uptake and metabolism of diclofenac in Typha latifolia-How plants cope with human pharmaceutical pollution. Plant Sci. 2014, 227, 12-20. [CrossRef]

44. Pierattini, E.C.; Francini, A.; Huber, C.; Sebastiani, L.; Schröder, P. Poplar and diclofenac pollution: A focus on physiology, oxidative stress and uptake in plant organs. Sci. Total Environ. 2018, 636, 944-952. [CrossRef]

45. Tripathi, A.; Gautam, M. Biochemical parameters of plants as indicators of air pollution. J. Environ. Biol. 2007, 28, 127. 
46. Hasan, M.K.; Cheng, Y.; Kanwar, M.K.; Chu, X.-Y.; Ahammed, G.J.; Qi, Z.-Y. Responses of Plant Proteins to Heavy Metal Stress-A Review. Front. Plant Sci. 2017, 8. [CrossRef]

47. Di Baccio, D.; Pietrini, F.; Bertolotto, P.; Pérez, S.; Barcelò, D.; Zacchini, M.; Donati, E. Response of Lemna gibba L. to high and environmentally relevant concentrations of ibuprofen: Removal, metabolism and morpho-physiological traits for biomonitoring of emerging contaminants. Sci. Total Environ. 2017, 584-585, 363-373. [CrossRef]

48. Calderón-Preciado, D.; Jiménez-Cartagena, C.; Matamoros, V.; Bayona, J. Screening of 47 organic microcontaminants in agricultural irrigation waters and their soil loading. Water Res. 2011, 45, 221-231. [CrossRef]

49. Pietrini, F.; Di Baccio, D.; Aceña, J.; Pérez, S.; Barceló, D.; Zacchini, M. Ibuprofen exposure in Lemna gibba L.: Evaluation of growth and phytotoxic indicators, detection of ibuprofen and identification of its metabolites in plant and in the medium. J. Hazard. Mater. 2015, 300, 189-193. [CrossRef] [PubMed]

50. He, Y.; Langenhoff, A.A.; Sutton, N.B.; Rijnaarts, H.H.; Blokland, M.H.; Chen, F.; Huber, C.; Schröder, P. Metabolism of ibuprofen by Phragmites australis: Uptake and phytodegradation. Environ. Sci. Technol. 2017, 51, 4576-4584. [CrossRef]

51. Hawkins, T.S.; Gardiner, E.S.; Comer, G.S. Modeling the relationship between extractable chlorophyll and SPAD-502 readings for endangered plant species research. J. Nat. Conserv. 2009, 17, 123-127. [CrossRef]

52. Lichtenthaler, H.K.; Welburn, A.R. Determination of total carotenoids and chlorophylls a and b of leaf extracts in different solvents. Biochem. Soc. Trans. 1983, 11, 591-592. [CrossRef]

53. Porra, R.J. The chequered history of the development and use of simultaneous equations for the accurate determination of chlorophylls a and b. Photosynth. Res. 2002, 73, 149-156. [CrossRef]

54. Price, W.J. Analytical Atomic Absorption Spectrometry; Heyden and Son: London, UK, 1974.

55. Katz, S.A.; Jennis, S.W. Regulatory Compliance Monitoring by Atomic Absorption Spectroscopy; Verlag Chemie International: Tampa, FL, USA, 1983.

56. Velikova, V.; Yordanov, I.; Edreva, A. Oxidative stress and some antioxidant systems in acid rain-treated bean plants. Plant Sci. 2000, 151, 59-66. [CrossRef]

57. Heath, R.L.; Packer, L. Photoperoxidation in isolated chloroplasts: I. Kinetics and stoichiometry of fatty acid peroxidation. Arch. Biochem. Biophys. 1968, 125, 189-198. [CrossRef]

58. Beauchamp, C.; Fridovich, I. Superoxide dismutase: Improved assays and an assay applicable to acrylamide gels. Anal. Biochem. 1971, 44, 276-287. [CrossRef]

59. Aebi, H. Catalase in vitro. Methods Enzymol. 1984, 105, 121-126. [CrossRef]

60. Tiedemann, A.V. Evidence for a primary role of active oxygen species in induction of host cell death during infection of bean leaves with Botrytis cinerea. Physiol. Mol. Plant Pathol. 1997, 50, 151-166. [CrossRef]

61. Foster, J.G.; Hess, J.L. Responses of superoxide dismutase and glutathione reductase activities in cotton leaf tissue exposed to an atmosphere enriched in oxygen. Plant Physiol. 1980, 66, 482-487. [CrossRef] [PubMed]

62. Nakano, Y.; Asada, K. Hydrogen peroxide is scavenged by ascorbate-specific peroxidase in spinach chloroplasts. Plant Cell Physiol. 1981, 22, 867-880.

63. Bradford, M.M. A rapid and sensitive method for the quantitation of microgram quantities of protein utilizing the principle of protein-dye binding. Anal. Biochem. 1976, 72, 248-254. [CrossRef]

64. Andreotti, F.; Mucha, A.P.; Caetano, C.; Rodrigues, P.; Gomes, C.R.; Almeida, C.M.R. Interactions between salt marsh plants and $\mathrm{Cu}$ nanoparticles-effects on metal uptake and phytoremediation processes. Ecotoxicol. Environ. Saf. 2015, 120, 303-309. [CrossRef]

65. Wang, W.-X. Bioaccumulation and biomonitoring. In Marine Ecotoxicology; Elsevier: Amsterdam, The Netherlands, 2016; pp. 99-119.

Publisher's Note: MDPI stays neutral with regard to jurisdictional claims in published maps and institutional affiliations. 